| Volume-1 | Issue-1 | Jul-Aug 2019 |

Review Article

\title{
Fiction Films in the Educational Process
}

\author{
Lebyedyeva N.A* \\ PhD in Cultural Studies, Professor of International Personnel Academy in Kiev, the Authored Member of Eurasian Academy of \\ Television and Radio
}

*Corresponding Author

Lebyedyeva N.A

Article History

Received: 24.07 .2019

Accepted: 14.08 .2019

Published: 30.08 .2019

\begin{abstract}
The article discusses the genre of fiction films in the educational process. The study highlighted and analyzed relevant of film works to the educational process. The artistic features of mentioned films in the context of the educational process, their content as spiritual, moral, artistic and aesthetic are described. In the context of studying the features of the educational process, the involvement and use of cinematographic works in its framework becomes relevant. As it is known, the role of cinema in the system of culture is very important. After all, cinema art performs a special function in relation to society, the function of strengthening social ties between people, manifested in the need for spiritual involvement of the individual to society, because it is thanks to society and culture that a person forms his life values, priorities, ideals and worldview. Cinematography can form human qualities in every human individual, for it creates images of positive heroes that are a model of social behavior and consciousness that society needs. The purpose of the article is to reflect the specifics of the genre of fiction films in the educational process on the example of artistic techniques of films-winners of international youth film festivals. A descriptive method, a structural analysis method and an empirical study were used, consisting in viewing and selecting competitive works. The novelty of this article lies in the fact that films created by young directors, screenwriters and cameramen, who inherited the best traditions of children's films, are considered and described in the context of their significance for the modern educational process. Also the practical value of some of the films-winners of the international film festival "Light to the World" has been proved.
\end{abstract}

Keywords: festival, educational, process, films, expressive, fiction, light to the world, ideological and thematic.

\section{INTRODUCTION}

According to the definition of Doctor of Pedagogical Sciences M. Fitzula, the educational process is an integral part of the overall process of educating a comprehensively developed personality that meets the needs of modern society, which should ensure the fulfillment of this task by implementing three functions: educational, developmental and educational [12]. In the context of studying the features of the educational process, the involvement and use of cinematographic works in its framework becomes relevant.

As is known, the role of cinema in the system of culture is very important. After all, cinema art performs a special function in relation to society, the function of strengthening social ties between people, manifested in the need for spiritual involvement of the individual to society, because it is thanks to society and culture that a person forms his life values, priorities, ideals and worldview. Cinematography can form human qualities in every human individual, for it creates images of positive heroes that are a model of social behavior and consciousness that society needs.

The purpose of the article is to reflect the specifics of the genre of fiction films in the educational process on the example of artistic techniques of films-winners of international youth film festivals. To achieve the goal, the following objectives were set:

- To highlight and analyze current fiction film-winners out of 53 films-finalists of the international film festival;

- To consider the ideological and thematic features of the selected films;

- To characterize the figurative means of the films.

Copyright @ 2019: This is an open-access article distributed under the terms of the Creative Commons Attribution license which permits unrestricted use, distribution, and reproduction in any medium for non commercial use (NonCommercial, or CC-BY-NC) provided the original author and source are credited. 


\section{Material and Methods}

Fiction films are the material of this research. A descriptive method, a structural analysis method and an empirical study were used, consisting in viewing and selecting competitive works. The novelty of this article lies in the fact that game films created by young directors, screenwriters and cameramen, who inherited the best traditions of children's films, are considered and described in the context of their significance for the modern educational process.

\section{Analysis of recent publications and studies}

The works of many scientists are devoted to the study of the features of cinema. Each of them approached the problems of film and television in its own way and uniquely. These are the works of such researchers as G. Prozhyko [10], S. Saraplova [17], N. Marievskaya [5], V. Polukarova [9], L.Granovsky [9] , V. Kozina [9], V. Lozovskaya [9], N. Utilova [16]. Spiritual and moral education in the education system was considered by I. Plyasetskaya [8], N. Snopko [15]. Doctor of Pedagogical Sciences Hanna Oreshkina examined in details the methodological foundations of the continuity of the educational process in the system of continuous education [6].

During the V International Scientific Symposium "Humanitarian and social sciences in Europe: achievements and prospects", held in Vienna in 2014, it was noted that films from the Orthodox International Youth Film Festival "Light of the World" program that concentrates spirituality and love, being as "factors that keep the aggression, which is growing in people, imposed by "militants" and similar commercial television. Films presented at the festival are worthy of the attention of cultural scientists, art historians and television figures, on whom the rental activity depends. Orthodox movie can cultivate goodness and love in the hearts of people, resist aggression" [19].

\section{RESULTS ANd Discussions}

In studies on the art of cinema, such a film as children's cinema is distinguished as "cinema, created specifically for children and teenagers and named so by analogy with children's literature,. Children's cinema includes artistic and playful, animated and documentary, scientific and educational films designed for different ages - from children to youth" [2,]. If we talk about the genre originality of fiction films, the term itself is defined by a synonym for the artistic, thereby referring the reader to a dictionary entry about a fiction film. By definition, S. Yutkevich, Yu. Afanasyev, V. Baskakov, I. Vaisfeld, a fiction film is considered in two ways. The first one is "in the most common sense the same as a game film, that is, created on the basis of a scenario plot (usually fictional) interpreted by the director and embodied in acting, camera art, etc.)" [2]. Secondly, "in a broader sense, it is generally a work of cinema, that is, a film with artistic value and acting in an artistic function: it can be created not only in the forms of fiction, but also documentary, animated and popular science" [2].

Modern scientists also note that there are global manifestations that are evaluated negatively. "Thus, the interaction of cultures often takes place in the direction of the absorption by the Western cultural tradition of all other cultures, which threatens to blur the national identity of the population of countries that are drawn into globalization under the banner of westernization" [7]. As experience shows, this entails, to put it mildly, not very positive consequences. It is the educational process that can contribute to preserving the best traditions of the people, demonstrating the best examples of national cultures. In such sense, the use of fiction films within its demonstration during the education process is indisputable. Increasingly, the viewer is faced with the offer of his attention to the cultural product of the mass culture of the Western sample, and children are most affected by it, thanks to the global Internet. The ability to manipulate human instincts can cause fear for the future of the people, the bearer of their own cultural heritage. The president of the Eurasian Academy of Television and Radio, a well-known scientist, Ph.D. Valeriy Ruzin, in his article "The Sovereignty of Culture and New Challenges," noted that computer games are replacing television. "The younger generation spends up to 35 hours a week (this is almost a full-time work week) at the computer, communicating on the Internet, consuming digital content. Computer games constitute a significant proportion of adolescent communication, success in them increases self-esteem. This is the gateway through which the consciousness of the youth is formed today directly with the help of the meaningful content of these games. Obviously, the old means of forming a culture recede into the background: not only books, but also cinema and television are cultural attractors of different generations. For the new generation, such an attractor is the world of computer games" [13]. But life is not a computer game, where five and more lives are given to replace one life, and a player is able to resurrect the deceased.

Life is given to us once. That is why in the educational process it is so important to use fiction films to achieve education of a comprehensively developed personality. After all, a fiction film, as a rule, gives us aesthetic means: it is able to develop and educate with its artistry. After all, when we look at a work of art, where the plot is interesting, the talented actors, the light and color are right, the clear sound is heard, we, the audience, want to be like the characters of the film. Or, under the impression, we analyze our actions and conclude that there is "good" and that is "bad", and how another person can suffer if we act "bad" in relation to him. The film "Scarecrow" became such a classic example of a children's game cinema, like a mirror reflecting a problem that it was not customary to talk about in schools for a long time. A. R. Romanenko describes the reaction to this film: "The appearance of" Scarecrow "was greeted by some as something unexpected and frightening, like a gin from a bottle. Opinions about the picture were opposed. After a series of fresh, smoothed school tapes with pseudo-conflicts, reticence and omissions, the film of R. Bykov, frank, sharp, angry and kind at the same time, pressing many painful points at once, could not help but amaze the viewer" [12]. 
The film "Scarecrow" (script by V. Zheleznikov and R. Bykov, directed by R. Bykov), which became the classic of children's fiction films, does not lose its relevance. Lena Usoltseva is twelve years old and she is the "new" in her school. The girl refers humorously to the nickname that classmates gave her, accepting it as a game. But an innocent plot entails a dramatic conflict, manifested in a brutal boycott declared by classmates to Lena. The boy whom she liked, the main character, turns out to be a coward, and the girl takes his guilt upon herself. As a result, the class suits her "persecution." The betrayal of the first love hurts the little soul, but Lena's personality stamina delights the viewer. The lighting decision of the picture reflects the emotional experiences of the heroine. In this film work, each frame carries a certain function of expressing the author's idea, which is capable of being transmitted to the viewer, causing him sympathy, indignation, a desire to stand up for Lena, to stop this glaring injustice!

The continuation of the best ideological and thematic traditions laid down in the classic movie "Effigy" is found in the work of Maria Mozhar "For the Name of ... My" (studio "Orthodoxy"). The first thing that immediately attracts attention is the special color scheme of the painting, which transfers the viewer to the post-war era of the mid-twentieth century. The peculiarity of the director's decision are also Levitan landscapes that convey the mood of immutability of philosophical life. Women are going from the Kamenka village. Their "father disappeared," and now they are forced to look for another parish, another priest. The film intertwines different fates, showing mercy, kindness, love, the importance of the ability to forgive. Before the viewer unfolds the tragic story of a little girl who does not even know her own name. All persecuted, scored for all that her father was a policeman from the Germans, and, as we learn later, became the culprit of the death of the father of a large family. The authors of the film try to soften childish cruelty with the act of their mother, who gives her food to the unhappy girl. The main character of the film is father Alexander, who stands up for the baby, brings her into his house, feeds and sews her clothes, gives her a name. Is it necessary to be surprised that the unfortunate child searches for him in the forest all night, after people with guns come after him? How wise is the priest, explaining to parishioners that he is going to receive a medal, accompanied by NKVD employees, while his eyes are full of grief ... His every act contributes to peace, his every word teaches to love unconditionally life, neighbor and, of course, God. The culmination, in the opinion of the author of this article, is the frame where, against the background of the road receding into the distance, a crying girl runs after the cart, which takes away from her father Alexander with a cry "Mom!". She runs, then goes, then falls ...

The age-old pines and fog at dawn are an expression of the beginning of another life, thanks to a sound solution: the whole village is looked for a girl and called Anna. Everyone says her name affectionately in different ways: "Annushka!", "Anya!", "Annie!", "Anna!". The tragic story makes all the villagers realize love in the purest sense of the word, forgive and live together, stick together. Frames, where on a foggy morning Avdotya has many children on her hands, finally has found Anna, show the viewer the strength of the human soul, which she is capable of, forgiving the strongest offense. Now everything will be different. The role of Annushka is very sincerely played by Maria Korneeva. The talent of Vladimir Egorov, who played the father of Alexander should be noted. Convincingly embodied the images of Daniel and Pavel Rassomakhin, Sasha Matyukova, Elena Valyushkina, Alexander Nazarov, Anatoly Shcherbakov.

The electronic scientific journal "Universum: Philology and Art Criticism", included in many electronic databases, presents us with the article "Ideological, thematic and pictorial and expressive features of gaming and non-game films of the International Film Festival "Light to the World ", which describes the film "Cuffs". The emotional experiences of the main character of the film echo both the "Scarecrow" and the "For My Name ... Mine" film work discussed above in frames when the whole class accuses the girl of theft. Referring to the "Universum: Philology and Art Criticism": "The film makes you think that every act is important in childhood, every word, and there are no small problems. Children's souls, very vulnerable to the words and actions of adults. They may suffer all their life when they become adults. Fortunately, for the heroine of the film comes a positive outcome, this, in our opinion, is a feature of children's cinema: to lead the viewer to the light" [4].

The relevance of the fiction films "Leaflet" and "Juice of Pomegranate" was viewed abroad in the scientific article through the prism of a philosophical understanding of human problems in the cultural context of modern Orthodox cinema. These films also have very expressive artistic techniques. The fiction film "Leaflet" (directed by Roman Pozhidaev, Bashkortostan, author Zukhra Burakaeva) poses at least two problems for the viewer: saving folk crafts and traditions that need to be mastered despite modern technical advances, because they represent a link between generations, as well as value human life, which is compared with a leaf of a tree. The little boy, having heard the conversation between his mother and the doctor, regarding the state of his grandfather's health, tries to prolong the life of his relative by sticking a yellow piece to a tree branch. The film is interesting for its composition, color scheme, special poeticism expressed in the frames of the grandfather's dreams and a happy end.

Highly artistic and very professional film of joint production in Ukraine and Armenia, by the company "ARO-Film", (authors Andranik Davtyan and Roman Volchak) "Juice of Pomegranate". There is no text here because it is not needed. The film is dedicated to the tragic page of the history of the Armenian people - the 100th anniversary of the Armenian Genocide in the Ottoman Empire. Stunning beauty filled with a number of pictorial. These are mountain landscapes, a bird hovering over the sea, the endless expanses over which the Armenian churches tower. In all there is a dazzling white color. At the beginning of the picture we see the whiteness of the walls of the house where people live, their white clothes and white milk, creating a sense of innocence and purity. The tragedy is shown very artistically and symbolically, with a sharp movement of a cold weapon a grenade is cut on a white tablecloth, its red juice 
tells the viewer about bloodshed. The culmination shots of the conflagration, in which an image of a human face appears ... Eternal memory to the victims is expressed in frames where young people, holding lighted candles in their hands, stand, forming a tragic figure. The film was awarded by a diploma of the third degree of the Fifth International Youth Film Festival "Light of the World". This film work was also awarded by the 1-st Prize of the International Film Festival of Amateur Cinema "Kinokimmeria" under the patronage of "UNICA" ("UNICA" - International Cinema Association, member of the official council of UNESCO) [18]. In 2016, this film was exhibited to participate in the festival in Cannes.

\section{COnClusions And OfFers}

Summing up, the author of this article concludes that the value of fiction movie as a mean for developmental and educational functions is very great, because of having a direct impact on the human subconscious, it contributes to the socialization of a child, asserting it as an individual, attracting life, clearly explaining and showing certain historical events, pushing the person to philosophizing, reasoning and the ability to independently draw certain conclusions. Showing cinema films during the educational process, cognition itself is much better, since the synthetic art form, which is fiction cinema, gives the most complete and intelligible picture of the world for a growing personality.

\section{REFERENCES}

1. Griczenko, T. B., Griczenko S. P., Kondratyuk A. Yu. (2011). Cultural Stadies. - Kyev: Czentr uchbovoyi li teraturi.

2. Yutkevich, S. I., Afanasev, Y. S., Baskakov, V. E., \& Vaysfeld, I. V. (1986). Movie: Collegiate Dictionary. Moscow: Sov. Entsiklopediya Publ.[in Russian].

3. Lebedeva, N. A. (2015). Philosophical understanding of human problems in the cultural context of modern Orthodox cinema. Molodij vchenij, 126-130.

4. Lebedeva, N. A. (2015). Ideological, thematic and izobazatelno-expressive features of gaming and non-fiction films of the International Film Festival "Light to the World - 2015". Retrieved June 28, 2019, from Universum Universum: Philology and Art History: e'lektron. nauchn. zhurn.

5. Marievskaya, N. E. (2015). Time and Cinema. M.: Progress-Tradicziya.

6. Oreshkina, A. K. (2009). Methodological foundations of the continuity of the educational process in the system of continuous education. Moscow.

7. Sandyuk, L. O., Shhubelki, N. V. (2012). Fundamentals of Cultural Studies, Kyev, Czentr uchbovoyi li' teraturi,Ukraune.

8. Plyaseczkaya, I. A., (1998). Modeling of moral and aesthetic education in the system of additional education (on the example of children's creativity). Moscow.

9. Polukarov, V. L., (2004). TV and radio advertising . Moscow, ITK "Dashkov i K".

10. Prozhiko, G. S., (2004). The concept of reality in the on-screen document. Moscow, VGIK.

11. Fifth International Youth Film Festival "Light to the World" June 1-5, (2015). Rybinsk, Uglich, Myshkin, Borisoglebsky, Yaroslavl.

12. Romanenko, A. R., (1987). The world is fabulous and the world is real. Moscow, Iskusstvo.

13. Ruzin, V. D., (2015). Culture Sovereignty and New Challenges. Belaruskaya dumka, 1, 70-74.

14. Saral'pova, S. B., (2010). Problems and possibilities of television direction: ethnos through the prism of folk art. Nal'chik, Izd-vo M. i V. Kotlyarovy'kh.

15. Snopko, N. M., (2014). Reserves of the mechanism of moral regulation from the standpoint of management of the educational process, Aktual'ny'e problemy' sovremennoj nauki, N 4, 94-95.

16. Utilova, N. I., (2004). Installation. Moscow, Aspekt Pres.

17. Fi'czula, M. M., (2000). Pedagogy. Kyev, Vidavnichij czentr «Akademi' ya», Ukraine.

18. The $X$ International Festival of Amateur Cinema "Kinokimeria". Catalog. Kherson. (2015).

19. Lebedeva, N. A. (2014). Orthodox movie in the context of counterweight to aggression as "an alternative to evil". In Humanities and Social Sciences in Europe: Achievements and Perspectives (pp. 15-20). 